\title{
CONCERNING OPTIMIZATION OF THE SYSTEM MANAGING OPERATING AND TECHNICAL TRAFFIC MONITORING MEANS
}

\author{
Ravil Safiullin'1, Mukhtar Kerimov² \\ 1,2 Saint Petersburg State University of Architecture and Civil Engineering \\ 2-ya Krasnoarmeiskaya st., 4, St. Petersburg, Russia \\ 1 safravi@mail.ru
}

\begin{abstract}
Relevant issues of transport machinery functioning when using operating and technical monitoring means in the field of traffic safety assurance are revealed. Methodological approaches allowing determining the implementation degree of management functions assigned to the traffic monitoring system in a particular region are proposed.

A stochastic model for the evaluation of performance efficiency of the subdivisions, institutions and organizations ensuring the implementation of monitoring functions using automated traffic enforcement systems (ATES) is determined. Results of the study conducted include developed models, as well as a method and algorithm for optimizing the structure of the system managing operating and technical means of transport machinery traffic monitoring.
\end{abstract}

\section{Keywords}

Management systems, operating and technical monitoring means, efficiency evaluation criterion, optimization algorithm.

\section{Introduction}

The underdevelopment of traffic management systems applied in regions of the Russian Federation when using operating and technical monitoring devices, insufficient qualifications of experts $\rightarrow$ trained in this field, and the limited number of persons capable of determining the ideology of solving tasks for managing the agencies and institutions ensuring the operation of automated traffic enforcement systems (ATES) in regions of the Russian Federation prove the significance of the gap between management practice and theory and, thus, reveal the need to develop a method for the evaluation of functional efficiency of the system managing operating and technical means when using ATES.

The professional literature does not contain any works on the theory of traffic management using operating and technical monitoring systems, based on the description of their functional properties. Developments related to design and intended application of organizational structures ensuring the operation of automated traffic enforcement systems as well as quantitative evaluations of functional efficiency of such structures and numerous subsystems are poorly represented. However, the following general issues were studied in great detail: design of management systems and evaluation of their properties (Popov, 1988); systems for monitoring of dynamic systems (Evlanov, 1972); automated system analysis (Stabin et al., 1984); systems science and potential efficiency of complex systems (Fleishman, 1982), information reliability in such systems (Melnikov, 1973); structure evaluation (Tsvirkun, 1982), and structural analysis (Nechiporenko, 1977). The corresponding developments were implemented in various fields and can be used as a scientific base for studies on the issue discussed in this article.

\section{Main Part}

A concept as a system of views, ideas and principles constituting a general methodology for control over a complex systemic object applied to an ATES system is based on the following provisions:

- recognition of traffic safety as a property of a purposefully functioning ATES, and recognition of managing this property as elimination of the possibility for system operation in modes that do not comply with the standards and lead to road accidents;

-recognition of the following as the main monitoring tasks defining the management structure of the corresponding monitoring subsystem: obtaining information on the 
actual state of all ATES components, calculating the subsystem state parameters and corresponding quality indicators on the basis of such information; making decisions on their compliance or non-compliance with the regulatory requirements to system functional performance; determining causes for non-compliance and corresponding remedial measures;

- recognition of monitoring as a necessary price for obtaining information ensuring purposeful functioning of the entire ATES and implemented on the basis of the corresponding financial, physical and other resources;

- recognition of automating the processes of the system managing operating and technical monitoring systems by means of improving the quality and efficiency of the monitoring subsystem without changing its functions.

Activities of organizations in the field of managing operating and technical traffic monitoring systems represent a set of interrelated procedures aimed at achievement of a specific goal. Ordered actions aimed at solving the task of traffic monitoring with the use of automated traffic enforcement facilities to a specified level represent the procedures. Work as a procedure with tangible results is expressed by the following tuple (equation 1):

$$
x_{i}=\left(a_{i}, b_{i}, T_{i}\right)
$$

where $i$ - work (procedure) index;

$a_{i}=\left(a_{i 1}, a_{i 2}, \ldots.\right)$ - vector of the parameters characterizing the work result;

$b_{i}=\left(b_{i 1}, b_{i 2}, \ldots.\right)--$ vector of the resources allocated for work performance and achievement of the result;

$T_{i}$ - time required for work performance.

Adverse events characterized by ATES failures and defects as well as erroneous actions and violations of regulatory documents can occur upon performance of monitoring functions. Indicators describing those events represent the initial information for analysis, evaluation and study as well as development of activities and decision-making.

The evaluation of the performance efficiency of subdivisions, institutions and organizations ensuring the implementation of traffic monitoring using ATES is carried out according to such generalized criterion as the level of traffic safety $P_{T S}$. A method for the evaluation of the performance efficiency of subdivisions, institutions and organizations ensuring the implementation of traffic monitoring using ATES represents an established sequence of activities.

To evaluate the impact of the automated traffic enforcement system on traffic safety, it is necessary to conduct studies at several levels: at the first level, it is necessary to give an absolute estimate to the road accident; at the second level, it is necessary to analyze the impact of the automated traffic enforcement system on the number of road accidents, taking into account the accident place and type.

Information about each road accident suitable for the evaluation of system performance includes the following:
- the name of the section where the road accident was recorded;

- the date and time of the road accident;

- the place of the road accident;

- the lane where the road accident occurred and direction of the traffic;

- the road accident cause;

- the state of the road surface at the moment of road accident occurrence;

- weather conditions observed at the moment of road accident occurrence;

- the description of the road accident.

At the second level, the evaluation shall be based on the analysis and comparison of the traffic situation before and after the start of traffic enforcement system operation. Information about each road accident suitable for the evaluation of system performance includes the following:

- the date and time of the road accident;

- the place (kilometer point) of the road accident;

- the road accident direction;

- the description (type) of the road accident;

- the number of people killed and injured as a result of the road accident.

The best option of the automated traffic enforcement system shall be selected using the methods and software implementing the systemic criterion (the level of traffic safety). The process of creating anthologies (sets of information system objects and their classes which determine object behavior and changes together with the fundamental properties and interrelations between such objects) is greatly simplified in information systems designed for application in the organizations, activities of which are governed by laws and regulatory documents. Upon system formation, it is reasonable to use the following:

- a single hardware and software technological complex ensuring the unification of all procedures for information exchange between organizations and interacting subdivisions;

- a single system of regulatory documents ensuring the unification of the accounting items of public importance by the main attributes.

The level of traffic safety (TS) is determined by the optimum combination of the estimates for the efficiency of the functions implemented and their actual values for a specific period. To assess this level, the following model for evaluating the functional efficiency of organizations was developed:

$P_{T S}=P\left(v, Q_{f}, Q_{s}, H_{f}, H_{s}, F_{k}, Z_{f}, D_{f}\right)$

The following designations are accepted:

$U$ - management function (activities);

$\mathrm{H}_{f}$ - a criterion for evaluating the implementation of the organization management function related to data processing in a region for a specific period of time;

$\mathrm{Hs}$ - a criterion for evaluating the implementation of the organization management function related to the implementation of administrative punishments; 
$Q_{s}$ - an optimization criterion related to the implementation of administrative punishments;

$Q_{f}$ - an optimization criterion related to the functional efficiency of data processing.

The accepted factors are basic, but their list is not exhaustive. Their qualitative and quantitative composition depends, first of all, on the problem statement. Dependence of the level of traffic safety on various indicators can be represented as follows:

$$
P_{T S}=P\left(Q_{f}, Q_{s}, H_{f}, H_{s}, U\right)
$$

The stated optimization task is considered multicriterion. To solve it, we should choose restriction criteria.

The method developed allows determining the implementation degree of functions assigned to the traffic safety management system in a particular region.

The criteria developed make it possible to determine the generalized criterion (the level of traffic safety).

$$
P_{T S}=M\left[P_{i}\right]=\sum_{i=1}^{1}\left(P_{k i} \times H_{k i}\right)
$$

Based on the maximum value of the traffic safety level when using ATES, the optimum structure of the system managing operating and technical traffic monitoring means is established.

The evaluation of management system performance when using ATES facilities is carried out according to the level of traffic safety. The studies conducted revealed the following systemic factors:

- the efficiency of the management function at each level of system activity;

- the implementation degree of the management function in a particular region for a specific period of time.

The number of the criteria taken into account and their weightage for a particular region shall be determined by experts.
The efficiency of the management function is evaluated according to the following dependence:

$P_{k i}=P\left(U ; Q_{f} ; Q_{s}\right)$

The actual evaluation of function implementation is carried out in accordance with the following equations:

$$
\begin{aligned}
& H_{f}=H_{c}(n, C) \\
& H_{s}=H\left(S, S_{n}, W, W_{f}\right)
\end{aligned}
$$

where $n$ is the number of ATES, pcs.;

$C$ is the number of issued orders, [orders/year];

$S$ is the amount of penalties paid within a year, [RUB/ year];

$S_{b}$ is the amount of penalties, [RUB/year];

$W$ - the number of cases filed, [cases/year];

$W_{f}$ is the number of actually paid proceedings, [cases/ year].

Taking into account equations 6 and 7 , equation 3 can be rewritten as follows:

$$
P_{T S} F\left(v_{k}\right)=\max \left[F\left(v_{k}\right)\right]=\max \left[\sum_{i=1}^{y} P_{k i} H_{k i}\right]
$$

In case of stochastic nature of the criteria for evaluating the level of traffic safety, it is necessary to consider a stochastic single-objective problem (Table 1). Let us assume that the number of possible activities and the number of traffic safety estimates for each activity are finite.

This condition corresponds to reality as the evaluation process requires the use of random events characterizing traffic safety. It is convenient to perform the analysis in accordance with the recommendations given in work (Safiullin, Kerimov, 2016).

The left column of the table represents activities in the form of a function, $U_{1}, U_{2}, \ldots . U_{k}, \ldots . U_{t}$ and the top line

\begin{tabular}{|c|c|c|c|c|}
\hline \multirow[t]{2}{*}{$\begin{array}{l}\text { Activities, man- } \\
\text { agement functions }\end{array}$} & \multicolumn{3}{|c|}{$\begin{array}{l}\text { Evaluation of the function efficiency }(P) \\
\text { and function implementation }(H) \text { for various } \\
\text { structures }\end{array}$} & \multirow[t]{2}{*}{ Traffic safety indicator } \\
\hline & 1 & $i$ & $R$ & \\
\hline $\begin{array}{l}\text { Functions of the } \\
\text { first level } U_{1}\end{array}$ & & & & $P_{T S 1}=\mu\left[P_{1 i}\right]=\sum_{v=1} P_{1 i} H_{1 i}$ \\
\hline $\begin{array}{l}\text { Functions } \\
\text { of the second level } \\
U_{2}\end{array}$ & & & & $P_{T S 2}=\mu\left[P_{2 i}\right]=\sum_{v=2} P_{2 i} H_{2 i}$ \\
\hline $\begin{array}{l}\text { Functions } \\
\text { of the third level } \\
U_{3}\end{array}$ & & & & $P_{T S 3}=\mu\left[P_{3 i}\right]=\sum_{v=3} P_{3 i} H_{3 i}$ \\
\hline $\begin{array}{l}\text { Efficiency evalu- } \\
\text { ation }\end{array}$ & & & & $P_{T S} F\left(v_{k}\right)=\max \left[F\left(v_{k}\right)\right]=\max \left[\sum_{i=1}^{y} P_{k i} H_{k i}\right.$ \\
\hline
\end{tabular}
represents types of events (causes - factors). The useful effect of ATES operation mainly resides in the social

Table 1. A stochastic model for evaluating the performance efficiency of subdivisions, institutions and organizations ensuring the implementation of traffic monitoring using ATES 


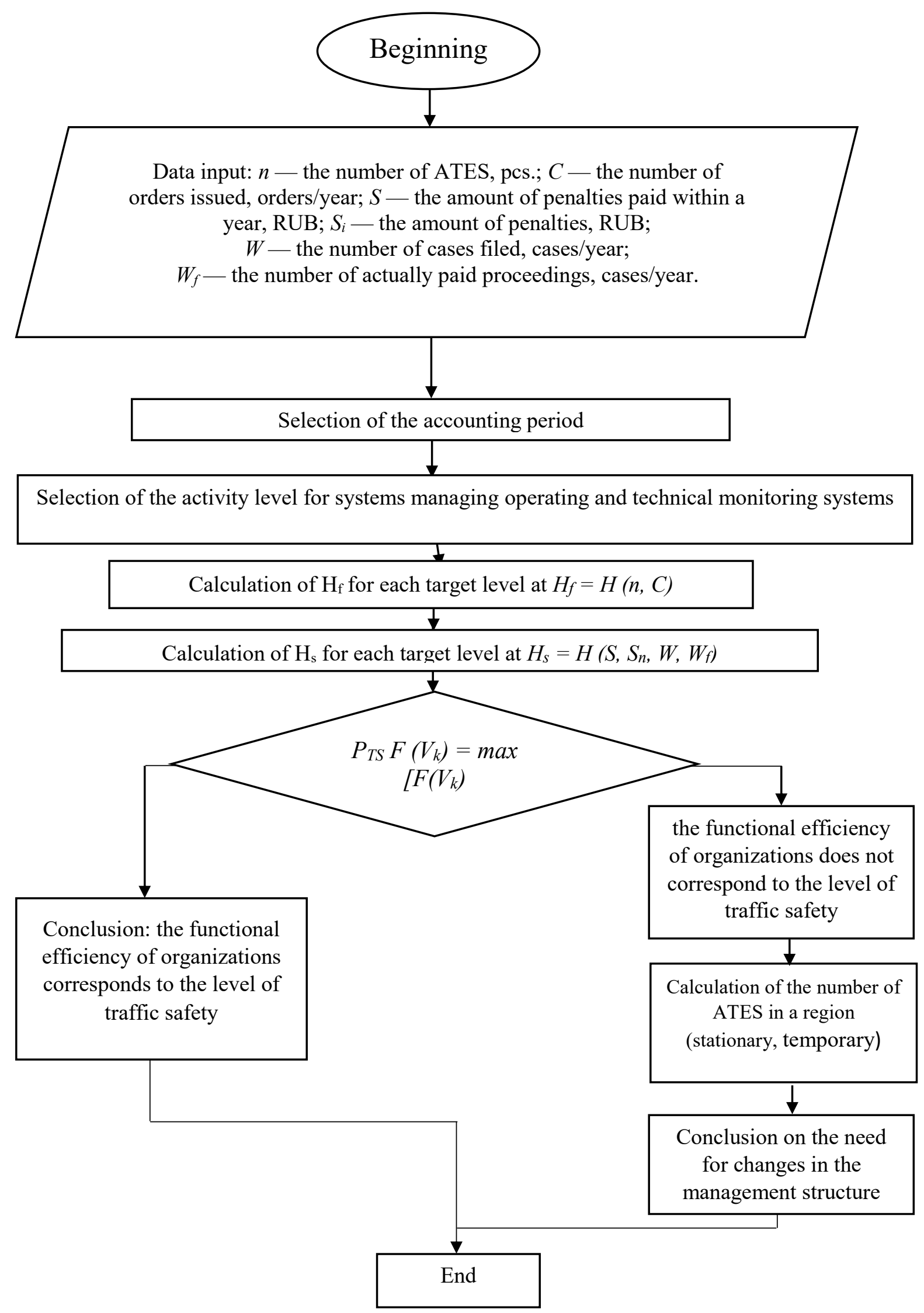

Figure 1. An algorithm for optimizing the system managing operating and technical traffic monitoring means 
significance of the complexes' functioning results, which can be evaluated by the indicator of a decrease in the accident rate on the monitored section of the street and road network ("accident cluster").

Another component of the useful effect is the number of administrative offences detected by the ATES facility. To evaluate the efficiency of system functioning, it is proposed to use an algorithm for optimization of the structure for managing operating and technical traffic monitoring means, which is shown in Figure 1.

\section{Conclusions}

The concept of the "optimum structure" for managing operating and technical traffic monitoring means should be considered as the best concept in the narrow sense, defined by the accepted optimization criterion. In this case, the level of traffic safety serves as such criterion.
Based on the studies conducted, it is possible to distinguish the following basic directions for improving the structure of the system managing operating and technical traffic monitoring means. Improvement of procedures related to management and technologies of processing data on recording of administrative offenses, modernization of the regulatory framework regarding recording of traffic violations when using technical monitoring system.

Typization of displaying information on objects of traffic violations, development of a hardware and software complex and equipment of the street and road network with the required amount of traffic enforcement facilities.

The efficiency of the management system operation is determined by the level of its interaction with concerned organizations and institutions, and, to a large extent, depends on the availability of the corresponding infrastructure and regional investment policy. 


\section{References}

Evlanov, L.G. (1972). Kontrol' dinamicheskih sistem [Control of dynamic systems]. Moscow: Nauka, p.423. in Russian)

Fleishman, B.S. (1982). Osnovy sistemologii [Fundamentals of systemology]. Moscow: Radio and communication, p.382. (in Russian)

GOST R ISO 14813-1-2011 (2012). Intellektual'nye transportnye sistemy. Shema postroenija arhitektury intellektual'nyh transportnyh sistem. Servisnye domeny $v$ oblasti intellektual'nyh transportnyh sistem, servisnye gruppy i servisy [Intelligent transport systems. The scheme to build the architecture of intelligent transport systems. Service domains in the field of intelligent transport systems, service groups and services]. Moscow: Standartinform, p. 120. (in Russian)

Kerimov, M., Safiullin, R., Afanasyev, A. (2017). Methodology for the improvement of control functions for traffic of road vehicles using systems of the automatic recording of administrative violations. Architecture and Engineering, 2 (3), pp.26-33. DOI: 10.23968/2500-0055-2017-2-3-26-33

Kerimov, M.A. (2015). Metodologicheskie osnovy vybora sredstv avtomaticheskoj fiksacii narushenij PDD [Methodological basis of auto-commit traffic violations]. In: Proceedings of the all-Russian Conference "Problems of the systems and vehicles study". Tula: Tula State University, part 1, pp. 107-110. (in Russian)

Melkinov, Yu.N. (1973). Dostovernost' informacii v slozhnyh sistemah [Reliability of information in complex systems]. Moscow: Soviet radio, p.192. (in Russian)

Nechiporenko, V.I. (1977). Strukturnyj analiz sistem. Effektivnost' i nadezhnost' [Structural analysis of systems. Efficiency and reliability]. Moscow: Soviet radio, p.216. (in Russian)

Popov, E.P. (1988). Teoriya nelinejnyh sistem avtomaticheskogo regulirovaniya $i$ upravleniya [The theory of nonlinear systems of automatic regulation and control]. Moscow: Nauka, p.256. (in Russian)

Safiullin, R., Kerimov, M., Marusin, A., Marusin, A. (2017). Evaluation of Functional Efficiency of Automated Traffic Enforcement Systems. Transportation Research Procedia, 20, pp. 288-294. DOI: 10.1016/j.trpro.2017.01.025

Safiullin, R.N., Kerimov, M.A. (2017a). Metodologicheskij podhod k formirovaniju i ocenke sistemy avtomatizirovannogo kontrolja transportnyh sredstv [Methodological approach to the formation and evaluation of the system of vehicles' automated control]. Vestnik grazhdanskikh inzhenerov [Bulletin of Civil Engineers], 1(60), pp. 246-252. (in Russian)

Safiullin, R.N., Kerimov, M.A. (2017b). Sovershenstvovanie kontrol'nyh funkcij sredstv avtomaticheskoj fotovideofiksacii administrativnyh narushenij avtomobil'nogo transporta [Improvement of control functions of automatic photovideo fixing of administrative violations of motor transport]. In: Proceedings of X International conference "Organization and road safety". Tyumen: Tyumen industrial University, pp.387-392. (in Russian)

Safiullin, R.N., Kerimov, M.A. (2016). Sredstva fotovideofiksacii narushenij PDD: normativnoe regulirovanie i praktika primenenija: [Methods of photo-video recording of traffic violations: control and practical application]. Moscow: Direkt-Media, p.355. (in Russian)

Safiullin, R.N., Kerimov, M.A. (2017). Intellektual'nie bortovie sistemi na avtomobil'nom transporte [Intelligent on-board systems in road transport]. Moscow: Direct Media, p.355. (in Russian)

Safiullin, R.N., Kerimov, M.A., Marusin A.V. (2015). O modelirovanii dorozhno-transportnoj avarijnosti pri ispol'zovanii tehnicheskih sredstv kontrolja narushenij PDD [On the modeling of traffic accidents with the use of technical means of monitoring traffic violations]. Prague: Publishing House "Education and Science", pp. 17-22. (in Russian)

Safiullin, R.N., Kerimov, M.A., Marusin, A.V. (2016). Povyshenie jeffektivnosti sistemy fotovideofiksacii administrativnyh pravonarushenij $v$ dorozhnom dvizhenii [Improving the efficiency of the system of photo and video fixation administrative offences in road traffic]. Vestnik grazhdanskikh inzhenerov [Bulletin of Civil Engineers], 3 (56), pp. 233-237. (in Russian)

Safiullin, R.N., Vorozhejkin, I.V. (2016). Perspektivy razvitija avtomatizirovannoj sistemy fotovideofiksacii administrativnyh narushenij $v$ RF $s$ cel'ju sozdanija informacionno-analiticheskoj sistemy vzaimodejstvija s intellektual'nymi bortovymi transportnymi sistemami [Prospects of development of the automated system of photo and video recordings of administrative violations of the Russian Federation with the aim of creating information-analytical system of interaction with intelligent onboard transportation systems]. Voronezh: Voronezh State University of Forestry and Technologies, vol. 1, pp. 342-347. (in Russian)

Stabin, I.P., Moiseeva, V.S. (1984). Avtomatizirovannyj sistemnyj analiz [Automated System Analysis]. Moscow: Mashinostoenie, p.309. (in Russian)

Tsvirkun, A.D. (1982). Osnovy sinteza struktury slozhnyh sistem [Fundamentals of synthesis of the structure of complex systems]. Moscow: Nauka. (in Russian) 